\title{
At Home, at Mine (chez moi). Return to Oneself
}

\author{
Petar Bojanić \\ University of Belgrade (Serbia) \\ University of Rijeka (Croatia)
}

\begin{abstract}
My intention is to reconstruct three "relational notions" (Popper) - house, homeland, and nostalgia - in order to show the violent strategies that determine them and on which they depend. Nostalgia and the idea of returning

to "oneself", along with various protocols of affirmation of identity, birth, and dwelling, imply interruption of
\end{abstract}

war and violence while also allowing for their possibility and renewal. The text affirms Clausewitz's notion of friction and reveals its potential for any possible theory of peace.

Keywords: nostalgia, house, homeland, friction, war

(c)Petar Bojanić; bojanic@instifdt.bg.ac.rs,bojanic@cas.uniri.hr

Colloquium: New Philologies, Volume 6, Issue 1 (2021)

doi: 10.23963/cnp.2021.6.1.9

Stable URL: https://colloquium.aau.at/index.php/Colloquium/article/view/155

This work is licensed under a Creative Commons Attribution 4.0 International License (CC BY 4.0). 


\section{Ich will heim, Ich will heim}

To reach the title and that which interests me most - the word "Heimat" - I would first like to take a roundabout way to also look at a few moments, perhaps crucial for a deconstructive or detective methodology.

First, I am interested in whether the house is an institution (an institution usually concerns a group of people - a minimum of three) and in the moment when it becomes an institution (which would be, for example, when it is defended or hosts an outsider, a guest, or is destroyed and exists only in the memory of a group of people, or serves as quarantine and protection against a virus). The house I mention is tied to the citizen returning (a citizen is by definition one who has exited the interior of the house and is affirmed by being in the spaces between houses), returning to a house that still in some way belongs to them. It is certainly not merely a house which one leaves or from which everything begins. ${ }^{1}$

Second, the homeland (the Serbo-Croatian words "dom" and "domovina" follow the English or German relation of home and homeland) implies a house that is not temporary or transient, and thus always more than a house as such: It is the surrounding landscape, the environment, homestead, and hearth tied to land and village, a city neighborhood, a territory ('territorial imperative' is Robert Ardrey's 1966 phrase).

Third, I would like to consider the action or activity that best describes what we call 'homeland' (Heimat). What action or engagement is crucial to confirm Heimat? In other words, in a paradox that perhaps explains this complicated construction better than anything, what protocol affirms the homeland by negating it?

I am certain that the discussion of Heimat must always begin anew with words that ought never to be ignored in the complicated histories of the phenomenon or figure or Mythos of "Heimat".

\section{Ich will heim, Ich will heim}

In paragraph 4 of his thesis Nostalgia oder Heimwehe, defended June $22^{\text {nd }} 1688$ at the Medical Faculty of the University of Basel, Johannes Hofer describes the grave injury and agony of a young peasant woman from a village near Basel. After falling from a certain height, she lay unconscious for several days and came to only after the application of various remedies and surgeries conducted in improvised conditions. Awaking and seeing unknown women taking care of her, she is overcome by nostalgia [Nostalgia statim corrept], says Hofer, after which she refuses all food, answering all questions with a single

1 "Home is where one starts from." (Eliot 1941, 26) 
phrase: "I want to go home. I want to go home." Her parents ultimately accept that she return home, even in her weak state [Tandem ergo a parentibus licet maxime imbecillis domum est delata] (Hofer 1688, 8; English translation 1934, 376-391), after which her condition improves suddenly and without any medication whatsoever. Hofer presents another case in the same paragraph: that of a young student from a wealthy family who travels to Basel for his studies but falls gravely ill. His condition improves rapidly after being sent home. These two cases allow Hofer to construct his argument about the appearance of an entirely new and unusual illness, explaining why Swiss soldiers were getting sick in large numbers.

What do I/we mean when I/we say, "I want to go home?"

The 'study' of nostalgia is tied to a vehement love for one's homeland, ${ }^{2}$ and as such nostalgia is a condition of interruption of war, as well as the condition for new war and violence. To begin with, or even before any beginning, in a preamble to any true study of nostalgia [die Heimweh-Lehre] (Ernst 1949, 57), let me offer two explanations or justifications that might support the framework of this text, or an introduction of the magical simulation of returning home, to oneself, to one's mother.

1. Hofer is the first to use the word "nostalgia" to indicate something well-known before him. He attempts to compile various cases defending the existence of an illness, as well as indicate treatments. The Swiss doctor's effort is only the beginning of a very long history of reconstruction of this phenomenon. Note that he arrives at a diagnosis of "nostalgia" by investigation or a "talking cure" with a patient. (Often, the therapist discovers entirely by accident that the patient's "state" is altered when either mentions the word "home", "childhood", "home region". This means that the therapy consists of recalling the patient's past, making the process of recollection overlap with the process and time of "recovery" in didactic form.) It is also interesting that this illness is "discovered" in conjunction with other problems (a fall from great height and a grave wound of the above-mentioned young woman; difficult course of study in a foreign land; great exertion on the part of the soldiers, etc.). All these other difficulties instigate a kind of retreat, regression or retardation, a desire to return, a going back ('to oneself', 'home', 'one's own', 'the before', 'to one's mother,' 'into coziness', 'indoors', 'inside,' 'the womb', ...). They cause a general state of insecurity, instability, and loss of solid ground under one's feet. The presentation of "nostalgia" could arouse violent behavior towards oneself or others since it requires a backwards move. The illness, paradoxically uniting women and soldiers, those committed to institutions and those expelled, those locked up and those lost, the

2 "Si cui verò magis arrideat Nostomanias aut Filopatridomanias appelatio, perturbatum animum ob impeditum in Patriam à qualicunque causa reditum denotans, per me omninó licebit." (Hofer, in Ernst $1949,62)$ 
displaced and renegades (the "illness" was noted in Switzerland across several languages, borders, and regions), assumes the existence of some obscure obstacles and presumes that it has to be "resolved" and be "liberated from" by someone else. The illness (which today has been relegated to "feeling" or "mood") is an expression of quiet or passive resistance in the form of disobedience, blindness, and rejection of authority. For example, there is rejecting the authority of parents who press their daughter into work and then have to accept her return from a far-away place; or rejecting the authority of the homeland, authority of a country's army over an individual, which yields before the illness to allow the recruit to return home. As a resistance to a higher or more powerful instance or force, nostalgia acquires the status of "alleged" illness that serves to malinger (avoid war, duty, work, service, discipline, community), while therapy for this supposed illness would only simulate - and thus confirm - its existence. Various quack doctors, from Hofer to Freud testify that it is enough for the patient to merely think, or utter, that they want to go home in order to feel better. In the same vein, it is also enough to convincingly malinger and simulate this illness to obtain "leave" from the authoritative body. In order to return home, it is enough to write, incessantly write.

2. Still, why is the construction or symptom of this alleged illness ("illness") present as the statement "I want to go home" [Ich will heim]? Why does nostalgia assume a register of speech turned to oneself, one not necessarily 'from oneself', 'from I', from speech in scare quotes, and why does it indicate a will to return? Once again, what do I/we mean when I/we say "I want to go home?"

And of course, what does "being at home" (chez moi) even mean? ${ }^{3}$

Presently, I would like to present a few ways in which nostalgia (or an "epidemic of nostalgia" ${ }^{4}$ ) is "paradoxical". I would like to describe its contentious nature, and explain the connection between nostalgia and the word "frictions" (which I write in italics and

3 Let us look at the way Paul Celan thematizes this 'chez moi. On the last page of Jean Améry's book Jenseits von Schuld und Sühne. Bewältigungsversuche eines Überwältigten (1966), Paul Celan notes "Heimat, Und Ich ? Ich war nicht einmal zuhause, als ich daheim (zuhause) war" (in Badiou’s translation: "Pays natal... Et moi ? Je nétais même pas à la maison, quand j’étais chez moi (à la maison)" (Celan 2004, 451, 459). Here we have Celan reading Améry's essay "Wieviel Heimat braucht der Mensch?" in this book, encountering the sentence "Ich war kein Ich mehr und lebte nicht in einem Wir." Heimat implies the existence of something more intimate than community as such - the existence of "Wir" and the belonging to that "Wir". Such a "Wir" is a fictitious first entity that implies any future thematization of Heimat or loss of Heimat. Heimat, entirely different for all members of a community, becomes the integrative factor for all of us, making us closer and more equal as members of the community. We are connected if and only if each belongs to their own native land, that is to say everyone is at home. The condition that we are all together is satisfied if each of us is in their own (real) placeand belongs to their original "Wir". One without a native land, paradoxically, is not part of the community or not part of us all. One without their "Wir" does not exist or will soon cease to exist.

4 In Greek, epidemos designates the awareness of a Greek man belonging to his homeland; it stands in contrast to the word apodemos, which describes a state of suffering due to being far away from one's homeland. 
plural). Clausewitz was the first to "produce" this word into a notion and used it exclusively in the singular. In German and in Serbo-Croatian, nostalgia is feminine and designates friction. For Clausewitz, nostalgia (mal du pays or "mocka nо pодине" as Vladimir Jankélévitch [1974, 276 $]^{5}$ reminds us) is indeed another element that leads to friction, obstructs military operation, invites desertion, interrupts war and brings peace. And vice versa: the return home is a return to a new war. Histories of return, from Homer, Virgil, and Dante, assume a certain conduct of violence (on his way home, Odysseus constantly uses cunning, cheating, murder; or elsewhere, fleeing violence does not prevent Aeneas from also committing it). Remaining in one's birthplace, in the province, introduces us all too easily to sundry visions of protection and safety, that is, it incites us to search for the guardian of the house, the sovereign and master.

When I say paradox I mean that nostalgia is always surrounded by some kind of violent strategy (which is, after all, the nature of any knot, riddle, or aporia). Tarkovsky further explicates this "paradox" ${ }^{6}$ He adds the Cyrillic letter " $\mathrm{H}$ " (Nostalghia) to the title of his film to prevent Italian viewers from reading it as if it were their word, and while Andrei speaks Italian in the film, his inner monologues are in Russian. The film is "soaked" with water constantly leaking (gathering, running off, seeping through), and Andrei's dialogues are in Italian while his inner monologues are in Russian. Between minutes 15 and 17, Andrei insists that poetry, like music, cannot be translated; that is that no one (in this case, the Italian woman) has any idea about Russia. When his own translator Eugenia attempts to soften these words, mentioning that the translator of the Russian poet Tarkovsky into Italian is himself a poet and that translation is necessary for people to interact, Andrei first notes how miserable (we) Russians are in not being able to understand Dante, Petrarch, and Machiavelli, and offers his maximalist recipe of communal life and mutual understanding: "Borders should be destroyed [distruggere le frontiere]", "state borders should be destroyed [dello stato]."

Should we immediately forget these two last sentences ("borders" in the plural, "state" in the singular; "destruction" as a surprisingly brutal word), as these words are arbitrary and seemingly uttered without any additional motivation? How can we connect and hold together two positions: that there is something in me (such as something "Russian") which is entirely "my own" and obscured from others, and at the same time a demand for states and borders to be destroyed? If the state (singular) did not exist, would we really be together, would we have a single language, and would individual memories thus

5 Jankélévitch's text on nostalgia is the sixth chapter, 276-313.

6 "I wanted to make a film about Russian nostalgia - about the particular state of mind which assails Russians who are far from their native land. I wanted the film to be about the fatal attachment of Russians to their national roots, their past, their culture, their native places, their families and friend." (Tarkovsky 1989, 202) 
disappear, and with them nostalgia? Or conversely, is nostalgia awoken by the thwarted return (for example, I have run away and now no longer possess papers allowing me to return)? Or, in order to arrive in the first place, do I have to destroy all obstacles on my way? A solution to this confusion in Tarkovsky's dialogue could be found in the histories of construction discourses on nostalgia. From Johannes Hofer and Rousseau to Jaspers, Heidegger, Popper or Freud, it is perhaps possible to eke out a few moments that determine the figure of nostalgia.

a) Nostalgia (just like allergy, homoeopathy, etc.) is an invented Greek word and a great etymological construction (das Heim-weh is also a new German word) created by Hofer in his late seventeenth-century dissertation, and which he juxtaposes with the French phrase Maladie du Pays (cf. Dodman 2018, 22). Hofer (although by no means he alone) lived in the Alps, was in touch with the Italian, German and French languages, wrote his thesis in Latin, and constructed the word for "his own" illness in Greek: nostos is Reditum in Patriam (the 1779 German translation renders this as "die Rückkehr ins Vaterland"), while algios is dolorem aut tristitiam in Latin [and Schmerz oder Betrübnis in German], and weh from das Heim-weh (Ernst 1949, 62-63).7 “'Homeland', 'return to the homeland' and 'pain' are the first and basic elements of nostalgia.

b) Nostalgia was first an illness, then a feeling (Bernet 2006, 87), then a state or mood [Heimwehverstimmung] for Jaspers, and finally, a linguistic or discursive product [DiskursProdukt] (cf. Bunke 2009, 25). Nostalgia first referred to the homeland or fatherland (Zwinger and Hofer came up with Pothopatridalgija and Filopatridomanija ${ }^{8}$ ), and quickly becomes a cry for a return to one's home (Ich will heim), to one's parents, loved ones, childhood, etc. Finally, Freud speaks of prenatal separation: the fact that the female sex organ [das weibliche Genitale] has something Unheimliches for "neurotic persons", reveals the entrance to one's ancient homeland [alte Heimat], towards which all humanity turns. Liebe ist Heimweh (2001, 112-113), Freud continues in the same passage, quoting a traditional saying that explains the nature of the unconscious as an encounter with the unbeimlich. ${ }^{9}$

\footnotetext{
7 The most detailed etymological analysis of the word nostalgia and the German Heimweh can be found in Nostalgie in der Geschichte der Medizin by Klaus Brunnert (1984, 29-43). In the introduction, Brunnert finds that prior to Hofer there were two traces of nostalgia being recognized as an illness or a medical phenomenon: Six Spanish soldiers between 1634 and 1644 during the Thirty Years' War were declared to be suffering from el mal de corazón or estar roto, while the word Heimweh was used for the first time in 1569 by Ludwig Pfyffer von Altishofen.

8 Hofer, writing De Hydrope uteri [uterine water], joins filia with patria and mania, while Zwinger reprints Hofer's dissertation in 1710 under a different title, De Pothopatridalgia, vom Heimwehe, systematically replacing the word nostalgia with pothopatridalgia (potos, patris, algos) (Prete 1992, 60).

9 Freud prefers Schelling's explanation of this untranslatable word: "this word designates what ought to remain a secret, hidden [im Verborgenen] ... and yet has appeared [hervorgetreten]." (Freud 2001)
} 
c) The illness first affected Swiss soldiers serving in the French or some other foreign army. Later, even toward the late nineteenth century (Jaspers' dissertation is the last great systematic attempt to examine nostalgia in the context of crime and violence), ${ }^{10}$ the paradigmatic patients are girls sent by their parents to boarding schools or to work in other family homes, as au-pairs and maids. They murder the children they care for or set fire to the houses in which they work, all with the aim of being sent home .

d) Music or various patriotic songs rouse epidemics of great nostalgia among soldiers, as witnessed by military doctors and generals. Jean-Baptiste Du Bos, writing in 1719, says that in less than three months, more than six thousand people died in a single city. Rousseau, in a letter to Marshal de Montmorency-Luxembourg of January $20^{\text {th }} 1763$, writes about the song ranz-des-vaches, mentioning the illness this song causes, called Hemvé (Rousseau 1972, 52). Dukes and commanders passed the death sentence on those singing such songs.

e) "Nostalgia is a form of melancholy caused by the ennui of being with foreigners who do not like us. It seemed to me that I had discovered", writes Albrecht von Haller in the Dictionnaires des Sciences, des Arts et des Métiers in 1777, "that one of the reasons for nostalgia lies in the political order of Switzerland. Very few foreigners frequent there and nearly none is able to remain since the right to live there is tied to birth and blood. [...] families from the same place (in the Alps) marry amongst each other, almost never mixing with outside blood."11

The always assumed but never sufficiently elaborated connection between nostalgia and melancholy is usually bridged with a "third" element that both have in common: "the loss of a loved person, or to the loss of some abstraction which has taken the place of one, such as one's country, liberty" (Freud 1964, 243), "loss of object" (Agamben 2006), "awareness of something distant, consciousness of something far away (conscience d'un ailleurs), the awareness of contrast between the past and present, between the past and future" (Jankélévitch 1974, 280-281), hypochondria or hysteria. ${ }^{12}$

${ }^{10}$ In his thesis, Jaspers (1963 [1909], 1-84) analyzes twenty case of serious crimes rooted in the desire to end exile and forcibly return to one's parental home.

11 "I have seen this malady several times and can speak of it with certainty. It is melancholy caused by a strong desire to see one's parents..." (Ernst 1949, 116-117).

${ }^{12}$ A medical report on the state of some freshmen cadets of the Naval Academy in Annapolis states that "melancholy and nostalgia are the most common symptoms of the hysterical state of these young boys" (cf. Bunke 2009, 240). 
f) The only remedy for this illness is a return to one's homeland and home. Various cases from the eighteenth and nineteenth century show that just thinking about returning (or just departing for home) is sufficient to improve the mood or even recuperate. ${ }^{13}$

g) The history of nostalgia is a history of "cases", testimonies, but also confessions. In $\$ 30$ of Anthropology, Kant says that an experienced general told him about the nostalgia of the Swiss. When they finally do return to their mostly poor regions, their homeland, they still do not find the time of their childhood.

h) Nostalgia is pure fiction (Nostalgie feinte [nostalgia simulate] (Bunke 2009, 116117), ${ }^{14}$ in the words of Meyserey or de Sauvages in 1763, and later Starobinski) and exclusively a symptom of the presence of another illness. It is malingering and "contagious" in so far as it is transmitted by talking (discourse, discussion, conversation, in words). ${ }^{15}$

Now, the last two examples that construct the great history of the figure of nostalgia should be thought first and always together. As soon as Andrei (Tarkovsky) utters the words "No one understands me (us)", or "Borders should be destroyed", there is something prearranged and pathetic, something "hypocritical" in nostalgic protocols. Still, it will certainly not be sufficient to simply displace nostalgia, as some kind of fantasy, into literature or pure fantasy. Kant attempted to liberate nostalgia from its spatial dimension, to determine it economically and ascribe it to the poor. He sought to remove it entirely from the homeland (because the return to homeland leads to death, Qui Patriam quarit, Mortem invenit ${ }^{16}$, but also because the homeland is where all is well [patria ubi bene]. In this way, Kant opposed the nineteenth-century notion of the European hungry for gold, digging for it on another continent, anxiously awaiting his return home ${ }^{17}$ - all of which is dealt a death blow by Martin Heidegger and the hermeneutics of old texts. It is not only a matter of Heidegger's reduction of everything to nostalgia and discovery of hidden nostalgia [verborgene Heimweh], or a return to linking Heimweh with

\footnotetext{
13 "The source of this despair was not difficult to reveal. I say reveal, for it was nearly impossible to pry a confession from this type of patient, none would admit what he suffered. They were all, so to speak, ashamed about the pain they felt, although they were betrayed by the joy that would sparkle in their eyes at the mention of promised leave." From the report of Denis Guerbois, army surgeon and first person to defend a thesis on nostalgia in French (1803). The quote is from A. Bolzinger $(2003,101)$.

${ }^{14}$ F. B. de Sauvages differentiates between three types of nostalgia: simple [simple], which is common among soldiers and can be repressed on the condition that soldiers find ways to have fun, can be dissuaded, or are on occasion given what they want (i.e. a return home?); complex [compliqué], which cannot be cured by any medicine but only if the soldiers actually run away or go home; and feigned [feinte], that is, simulated and imagined in order to avoid service (cf. Ernst 1949, 96-100).

15 Two famous texts by Starobinski attempt to show the fictitious nature of nostalgia: J. Starobinski, "The Idea of Nostalgia" (1966) and "Sur la nostalgie. La mémoire tourmentée" (2003).

${ }^{16}$ In his most detailed analysis of nostalgia to date, Simon Bunke interprets this position by Bernandino Ramazzini from 1700 on pages 90-92 (cf. Bunke 2009).

${ }^{17}$ P. Pinel, “Encyclopédie méthodique. Médicine” (1821) (Prete 1992, 740).
} 
Heimat (soil, house, or roots) but there is also an insistence on the importance of 'proximity', 'one's own', and then a hysterical repetition of a never fully deconstructed idea taken from Humboldt about the inseparability of language [Sprache] and homeland [Heimat]. It seems to me that Humboldt's famous sentence from his 1827 letter to Charlotte Diede, "Die wahre Heimat ist eigentlich die Sprache" (Von Humboldt 1848, 322) - with all its various incarnations and repetitions from Fritz Mauthner, Else Lasker-Schueler and Hannah Arendt to Derrida and Gadamer - still fits well in Heidegger's speech on the occasion of the $700^{\text {th }}$ anniversary of his hometown of Messkirch: "Unsere Sprache nennt den Zug zur Heimat das Heimweh" (Heidegger 2000, 578). What we should recognize in the strength of language - the strength of our language to name our own aspiration with the word "nostalgia" ( $Z u g$ is a sudden, fierce, and abrupt tug) - is the passion towards the homeland with which Tarkovsky at once excludes other languages and protects his own interior Russian language. It is the same force that calls for the destruction of borders.

I would like to insist on the point that Heidegger's 'return' from the Alps to the Alps, to Schwarzwald (such as in Hoelderlin's poem "Heimkunft", analyzed in detail by Heidegger, in which the poet returns in 1801 from Switzerland to his home region). Namely, this always assumes a return to traditional characteristics and uniforms: Nostalgia, in a word, revives nausea and war-time uncertainty. Further, it seems that several of Heidegger's most important inversions regarding Heimat still remain in the registers of nostalgia and thus produce or assume violence. Heidegger's (or Andrei's) insistence on the untranslatability of language, as well as on "private language", nurtured regional dialects, the power of the idiomatic (which is to say one's own region) all fit within the various theories of the 'unrepeatability' of the other, which we see in the theories about the foreigner or the Other in Lyotard, Levinas, or Deleuze. In demonstrating that no author feels at home in their language and that all language, even one's mother tongue, is completely foreign, Deleuze paradoxically reiterates Heidegger's and Andrei's position that there is something within us that is exclusively "ours" (untranslatable, unrepeatable, indivisible with others, incomprehensible to others, uncommunicable, and unpresentable). To be a foreigner or the Other assumes the existence of a homeland (such as Israel in Levinas, or some imaginary territory outside a given state's territory) even when it is claimed that the time of the house has irretrievably passed (Adorno 1951, $₫ 18^{18}$ ). The sentence "No one understands me (us)" (a position that includes the sentence "I want to go home") produces irreducible difference and foreigners, that is to say, a foreigner who necessarily

\footnotetext{
${ }^{18}$ One of the available English translations is rather infelicitous: "not to be at home in one's home." "Es gehört selbst zu meinem Glücke, kein Hausbesitzer zu sein', schrieb Nietzsche bereits in der Fröhlichen Wissenschaft. Dem müßte man heute hinzufügen: es gehört zur Moral, nicht bei sich selber zu Hause zu sein." (Adorno 1951, 58)
} 
produces foreigners around them. In that same way, the sentence "Borders should be destroyed" (which can also assume the line "I want to go home" if understood as "I do not wish to have any obstacles on the way home") assumes that the world ought to be one big house, and we always be at home. Learned people and philosophers (socalled intellectuals) - this is always the warrant and preliminary conclusion - ought to turn the world into a home because "philosophy is true nostalgia, desire to be at home anywhere" [Die Philosophie ist eigentlich Heimweh, ein Trieb, überall zu Hause zu sein] - a title by Novalis that Heidegger analyzes in $₫ 2$, at the beginning of the 1929 winter semester (Heidegger $1983, \S 2 b, 7-10){ }^{19}$

It seems to me that if the institution of philosophy would like in the future to free itself from such monstrous constructions - to find its own space once again between the houses, in the streets ${ }^{20}$ - it is not enough to merely follow and re-actualize Kant's sobering positions on true philosophizing that protects us from illnesses of the mind, from longing [Sehnsucht] for other worlds, and also from nostalgia [Heimweh]. ${ }^{21}$ It is imperative for the institution of philosophy to continuously uncover and acknowledge its explicit and implicit responsibilities for sundry wars and violence in history. ${ }^{22}$

Why then do I need von Clausewitz's "friction" [Friktion] to describe how nostalgia functions? Clausewitz first mentions the word Friktion in a letter (September 29th 1806) to his future wife. He writes of difficulties that one of the commanders, Scharnhorst, had in running the Prussian army; Clausewitz considered him as very talented, but says he

${ }^{19}$ We certainly need an analysis of the later interpretations and transformations of this "saying" by Novalis in Lukacs (in The Theory of the Novel) and Adorno and Horkheimer (in Dialectic of the Enlightenment).

20 This project actually requires the reconstruction and revalorization of one of Karl Popper's first texts, "Zur Philosophie des Heimatgedankens" (1927). Popper is very precise in defining Heimat and the house as relational notions, insisting on the importance of education that 'demystifies' the dogmatism of the house and the closure of the homeland. Here are Popper's opening lines: "The notion of homeland is certainly a prime example (Musterbeispiel) for what is, in contrast to the clear logical concept, called a 'psychological notion:' a collection of more or less vague notions, memory images, joined by a few elements of terminological nature ('place of birth')" (Popper 2006 [1927], 10).

21 “Der Kritik der reinen Vernunft ist ein Präservativ für eine Krankheit der Vernunft, welche ihren Keim in unserer Natur hat. Sie [diese Krankheit; Erdmanna's addition] ist das Gegenteil von der Neigung, die uns an unser Vaterland fesselt (Heimweh). Eine Sehnsucht, uns ausser unserm Kreise zu verlieren und andere Welten zu beziehen.” Note 5073, written between 1776 and 1778 (Kant 1928, 80).

${ }^{22}$ It is also imperative to revive and analyze some complicated and entirely forgotten positions. One such is recalled in 1952 by Erich Auerbach towards the end of "Philologie und Weltliteratur" (translated into English by Maire and Edward Said). Auerbach mentions a passage from Hugh of Saint Victor (from Didascalicon III, 20), a twelfth-century Saxon monk, on exile as a mode of life preferred by the man of learning: "It is, therefore, a great source of virtue for the practiced mind to learn, bit by bit, first to change about in visible and transitory things, so that afterwards it may be able to leave them behind altogether. The man who finds his homeland sweet is still a tender beginner (delicatus); he to whom every soil is as his native one is already strong (fortis); but he is perfect to whom the entire world is as a foreign land (perfectus vero, cui mundus totus exsilium est). The tender soul has fixed his love on one spot in the world; the strong man has extended his love to all places; the perfect man has extinguished." (Auerbach 1969, 17) 
would become completely paralyzed and pacified in the face of constant friction of other, different opinions. Scharnhorst cannot resist the friction 'emitted' by various advisors in the headquarters or in his offices and cannot make the decision to start up the 'war machine.' This example allows Clausewitz to imagine a grandiose military leader who would use his force of will to defeat anything in his way, that is, the myriad frictions of various elements. Anything that slows down the "movement" of war, all the obstacles and problems that obstruct military activity, paradoxically bother the commander, interrupt fighting, and probably bring peace. In Chapter Seven, "Friction in War" [Friktion im Kriege], of his book on war, Clausewitz writes:

Friction is the only concept that more or less corresponds to the factors that distinguish real war from war on paper [was den wirklichen Krieg von dem aufdem Papier unterscheidet]. The military machine [militärische Maschine] - the army and everything related to it - is basically very simple and therefore seems easy to manage. But we should bear in mind that none of its components is of one piece: each part is composed of individuals [Individuen], every one of whom retains his potential of friction. (Von Clausewitz 2007 [1832], 66)

Contrary to Clausewitz, but thanks to him, we know that if we wish to somehow interrupt war or foil it, it would appear that we must make things more, not less complex, always introducing new elements into play, onto the stage, into the open. We should also pay particular attention to what Clausewitz calls the "war on paper". Nostalgia is certainly one of the most important frictions; it obstructs and temporarily interrupts aggressive war, opening space for defense. Soldiers daydream of their homes; let us imagine them slowly returning to their homelands and houses. Yet, does the existence of one's house not already assume the readiness to protect it - protect and secure the idea of ownership, hide the path towards it, destroy (for oneself) the obstacles and borders on that path, to defend (with others, certainly) the "principle of the house" from less nostalgic intruders? Consider, as an illustration of this paradox, the Serbo-Croatian verb "braniti": it is the root verb of both odbrana, defense, but also zabrana, prohibition. The phrases braniti kucu and braniti princip kuce could be translated as defending the house, that is, defending the principle of the house; but they also mean banning or barring (the other) from the house, thus denying (to others) the house, denying them the principle of the house. The existence of one's own house, always a latent "nostalgia on paper", implies the existence of a house that is no longer a house, holding continuous conflict [stasis] of ideas, sex, gender, engendering, generations... a house in whose name it is impossible to go to war and for which it is impossible to fight. For this reason, Clausewitz's phrase, "war on 
paper", can, paradoxically, as both a fantasy and fiction of pure war - as friction - stop war and bring about peace. Still, I do not think war can be prevented if it is idealized, continuously constructed and planned, or incessantly written about. "War on paper" is above all supposed to evoke the origin of nostalgia in melancholy and in the misery of (learned) scholars [mysery of schollers] (Burton 1927 [1621],259-261), and means that there is an indestructible connection between nostalgic soldiers and experts for justifying the right to war and killing.

\section{Literatur}

Adorno, Theodor W. 1951. Minima Moralia. Reflexionen aud dem beschädigten Leben. Frankfurt am Main: Suhrkamp.

Auerbach, Erich. 1969. “Philology and Weltliteratur.” The Centennial Review 13 (1): 1-17.

Agamben, Giorgio. 2006. Stanze. La parola e il fantasma nella cultura occidentale. Torino: Einaudi.

Bernet, Rudolf. 2006. "Heimweh und Nostalgie." In Utopie. Heimat, herausgegeben von Martin Heinze, Dirk Quadflieg und Martin Bührig. 103-118. Berlin: Parodos Verlag.

Bolzinger, André. 2003. "Il y a deux cents ans, premières thèses parisienne sur la nostalgie." L'évolution psychiatrique 68 (1): 97-107.

Brunnert, Klaus. 1984. Nostalgie in der Geschichte der Medizin. Düsseldorf: Triltsch Druck und Verlag.

Bunke, Simon. 2009. Heimweh. Studien zur Kultur-und Literaturgeschichte einer tödlichen Krankheit. Freiburg: Rombach Verlag.

Burton, Robert. 1927 [1621]. The Anathomy of Melancholy, edited by Floyd Dell and Paul Jordan-Smith. New York: Tudor Publishing Co.

Celan, Paul. 2004. La bibliothéquephilosophique, ed. Alexandra Richter, Patrick Alac and Bertrand Badiou. Paris: Editions Rue d'Ulm.

Dodman, Thomas. 2018. What Nostalgia Was. War, Empire and the Time of a Deadly Emotion. Chicago: University of Chicago Press.

Eliot, Thomas S. 1941. Four Quartets, Part II, “East Coker”. London: Harcourt.

Ernst, Fritz. 1949. Vom Heimweh. Zürich: Fretz \& Wasmuth Verlag.

Freud, Sigmund. 1957. "Mourning and Melancholia." In The Standard Edition of the Complete Psychological Works of Sigmund Freud, Volume XIV (1914-1916): On the History of the PsychoAnalytic Movement, Papers on Metapsychology and Other Works, edited by James Strachey, 237258. London: The Hogarth Press and The Institute of Psycho-analysis.

Freud, Sigmund. 2001. Das Unheimliche und andere Texte: L'inquiétante étrangeté et autres textes. Paris: Gallimard.

Goddard, Jean-Christophe. 2006. "Schelling ou Fichte. L'être comme angoisse ou l'être comme Bonheur." In Le Bonheur, ed. Alexander Schnell. Paris: Vrin. 
Hofer, Johannes. 1934 [1688]. Dissertatio medica de Nostalgia, oder Heimwehe. Basel. English translation by Carolyn Riser Anspach. "Medical Dissertation on Nostalgia by Johannes Hofer, 1688." Bulletin of the Institute of the History of Medicine 2 (6): 376-391.

Heidegger, Martin. 1983. Die Grundbegriffe der Metaphysik. Welt-Endlichkeit-Einsamkeit, GA 29/30, herausgegeben von Friedrich-Wilhelm von Herrmann. Frankfurt am Main: Vittorio Klostermann.

Heidegger, Martin. 2000. “700 Jahre Messkirch.” In Reden und andere Zeugnisse eines Lebensweges 1910-1976, GA 16, herausgegeben von Hermann Heidegger, 574-582. Frankfurt am Main: Vittorio Klostermann.

Jankélévitch, Vladimir. 1974. L'irréversible et la nostalgie. Paris: Flammarion.

Jaspers, Karl. 1963 [1909]. Heimweh und Verbrechen. (Diss. Med). In Gesammelte Schriften zur Psychopathologie, 1-84. Berlin; Göttingen; Heildelberg: Springer Verlag.

Kant, Immanuel. 1928. Kants gesammelte Schriften, Vol. 18, Kants handschriftlicher Nachlass 3 , 5. Berlin: Walter de Grunter \& Co.

Popper, Karl. 2006 [1927]. "Zur Philosophie des Heimatgedankens.” In Frühe Schriften, (Gesammelte Werke in deutscher Sprache, Bd. 1.), herausgegeben von Troels E. Hansen, 10-26. Tübingen: Mohr Siebeck.

Prete Antonio, Ed. 1992. Nostalgia. Storia di un sentimento. Milano: Raffaello Cortina Editore.

Rousseau, Jean-Jacques. 1972. "Lettre à Charles-François-Frédéric de Montmorency-Luxembourg, maréchal-duc de Luxembourg," in Correnspondance complète de J. J. Rousseau, ed. by Ralph A. Leigh. Vol. 15, (letter no. 2440). Banbury: Voltaire Foundation.

Starobinski, Jean, and William S. Kemp. 1966. “The Idea of Nostalgia.” Diogenes 14 (54): 81103.

Starobinski, Jean. 2003. “Sur la nostalgie. La mémoire tourmentée." Cliniques méditerrainéenes 67 (1): 191-202.

Tarkovsky, Andrei. 1989. Sculpting in Time: Reflections on the Cinema. English translation K. Hunter-Blair. Texas: University of Texas Press.

Von Clausewitz, Carlvon. 2007 [1832]. On War. English translation B. Heuser. Oxford: Oxford University Press.

Von Humboldt, Wilhelm von. 1848. "Brief an Charlotte vom 21. August 1827." In Briefe von Wilhelm von Humboldt an eine Freundin, Teil 1, Leipzig. 